\title{
Penguatan Pembelajaran Sistem Daring
}

Ahmad Taufik dan Fitriyani

STAI Bumi Silampari Lubuklinggau

ahmadtaufik201902@gmail.com, fitriyani@staibsllg.ac.id

\begin{tabular}{ll}
\hline & Abstrak \\
\hline Article History & Schools as a community in providing \\
Received : 26-08-2020 & knowledge, both teachers, students \\
Revised :09-09-2020 & and parents must be alert about the \\
Accepted:19-09-2020 & clarity of the provision of supporting \\
\hline Keywords: & facilities for the provision of virtual \\
Schools, Virtual Learning, & learning. Facilities from the school \\
Technology & are very important dominantly in the \\
& meaning of the teaching and learning \\
& process. Teachers who are not \\
& familiar and old age need serious \\
& attention and technical guidance in \\
& the operation of technology so that \\
& older teachers are no longer confused \\
about virtual learning controls.
\end{tabular}

\section{Pendahuluan}

Dewasa ini masyarakat dunia dikejutkan adanya wabah COVID 19 yang sedang gencar dikabarkan bagi seluruh dunia, begitu juga negara Indonesia merasa sangat terganggu wabah Corona Virus Disease atau COVID 19. Masyarakat dunia kini disibukkan dengan upaya-upaya agar dapat terhindar dari virus ini. Dunia merupakan ajang kompetisi agar menjalin keakraban antar manusia untuk selalu berkomunikasi dan mengarahkan menjadi muslim (Ahmad Taufik, Khabar: Juni 2020). Karena jumlah masyarakat yang positif terkena virus ini hari demi hari semakin bertambah di Indonesia, bahkan sampai hari ini belum ditemukannya vaksin atau obat yang mampu menangkal virus tersebut. Berbagai upaya yang dilakukan oleh pemerintah pusat maupun pemerintah daerah untuk mencegah penyebaran virus ini, diantaranya pada daerah yang telah dinyatakan 
zona merah yaitu dengan tidak beribadah di tempat peribadatan, sampai-sampai lockdown.

Tentunya hal demikian membuat masyarakat dunia mulai merasakan dampak dari virus ini, baik berdampak pada sektor ekonomi maupun berdampak pada kondisi psikis masyarakat. Sebagaimana yang diungkapkan oleh Direktur program gangguan kecemasan di Yale Child Study Center, Fakultas Psikologi Universitas Yale, Amerika Serikat, "Eli Lewobitz menjelaskan bahwa virus COVID 19 ini belum dipetakkan sehingga adanya isolasi sosial, dan tindakan pencegahan dapat menimbulkan kecemasan dan depresi”.

Beralih pada sektor pendidikan, upaya pemerintah untuk memutuskan rantai penyebaran COVID 19 yaitu dengan penutupan sementara lembaga pendidikan baik dari tingkat TK sampai pada tingkat perguruan tinggi. Sehingga proses kegiatan belajar mengajar di kelas dialihkan menggunakan sistem daring. Pada system ini baik guru maupun peserta didik yang minim pengetahuan akan teknologi harus dituntut mampu menguasai media online. Walaupun pada hakikatnya daring tidak hanya sebatas pada media online saja, seperti halnya pengumpulan tugas peserta didik bisa dikirim langsung dengan cara menemui dosen atau guru yang bersangkutan, sehingga tidak diperlukannya media-media online (https://id.wikipedia.org/wiki/Penyakit_koronavirus, 22 Mei 2020 ).

Dari sektor pendidikan ini terlihat bahwa pandemik COVID 19 berdampak besar pada proses pembelajaran, diantara dampak besar tersebut adalah problem peserta didik yang biasa belajar langsung bertatap muka dengan gurunya, namun dengan adanya COVID 19 ini peserta didik diharuskan belajar menggunakan sistem daring. Hal serupa juga terjadi pada peserta didik yang berada pada daerah-daerah yang terpencil. Kurangnya fasilitas membuat mereka sulit sekali untuk belajar online, karena diakibatkan oleh keterbatasan sinyal yang ada. Bahkan banyak diantara para peserta didik yang tidak memiliki fasilitas untuk belajar daring, seperti smartphone. 
Mereka rela pergi jauh-jauh ke warung internet supaya mampu mengikuti materi via daring.

\section{Metode Penelitian}

Penulis melakukan penelitian dengan penelitian kualitatif diproses analisis dokumen data. Kajian dokumen dianggap sebagai analisis dokumen, yang terdiri buku, artikel-artikel, internet dan bahan-bahan yang sesuai dengan penelitian. Adapun cara-cara dalam pengumpulan datanya. Pertama, melalui kajian kepustakaan yang sesuai dengan bahan yang akan diteliti. Kedua, setelah data-data telah diperoleh oleh peneliti, maka selanjutnya menganalisis datanya melalui metode deskriptif sesuai dengan pemahaman penulis dalam melakukan kajian ini.

\section{Pembahasan}

\section{Pengertian Metode Quantum Teaching}

Sekolah yang bisa melaksanakan Quantum Teaching bagi para siswa dengan latar belakang dan strategi yang objektif dalam memberikan pembelajaran efektif dengan harapan para siswa merasa membahagiakan hati mereka (Muhammad Anas, 2014: 30). Quantum Teaching sangat memberi warna bagi dunia pendidikan yangmana para siswa mudah menerima materi pelajaran, paham etika pengajaran oleh gurunya dan saling kompak dalam pembelajaran (Zainal Arifin, 2013: 40). Banyak upaya-upaya yang dilakukan oleh guru dalam membuat strategi belajar baru yang lebih memberdayakan siswa, yang tidak mengharuskan menghafal fakta-fakta, tetapi strategi yang mendorong siswa mengkontruksikan pengetahuan dibenak siswa itu sendiri, salah satu diantaranya dengan menerapkan pembelajaran Quantum Teaching (Suharsimi Arikunto, 2010: 16).

Porter berpendapat mengenai pembahasan Quantum Teaching bisa menggelora dalam benak guru sehingga memiliki jati diri seorang guru yang ideal dalam pengajaran (Desmita, 2014: 28). Isi metode Quantum Teaching adalah cara baru dengan dilengkapi unsur-unsur seni dan pencapaian perencaan yang terarah sehingga pengajaran para guru sangat optimal (Jumanta Hamdayama, 2014: 40). Metode Quantum Teaching yang didapat oleh para guru melalui 
pencapaian secara istimewa dituangkan oleh guru yakni rencana pembelajaran yang memudahkan hasil belajar yang memuaskan (Suharsimi Arikunto, 2013: 26). Dewasa ini, banyak orang yang belum mengerti mengenai Quantum Teaching dapat dijadikan pijakan bagi para guru untuk melakukan kegiatan pembelajaran di dalam kelas (Ahmad Taufik, el-Ghiroh: Sep 2019). Quantum Teaching dilaksanakan oleh para guru dengan gaya belajar yang bisa mengetahui seberapa kemampuan- kemampuan para siswa dilihat dari keterampilan siswa dan motivasi siswa sehingga para guru dapat mengolah daya tanggap menghasilkan hasil belajar (Muhammad Dalyono, 2010: 18).

Quantum Teaching mengajak para guru lebih peka akan rangsangan hebat dengan beberapa karakteristik siswa yang bisa mendukung hasil belajar dan nilai yang memuaskan terutama harapan para orang tua meningkat (Miftahul Huda, 2014: 19).

\section{Tentang Novel Coronavirus (2019-nCov)}

Wabah pandemi yang meluas dibelahan dunia manapun adalah penyakit berbahaya disebabkan SARS-COV-2, Salah satu jenis virus ini tengah melanda musim pandemi di tahun 2019-2020. Wabah pandemi harus dihilangkan selama 2 hari hingga 14 hari dan bisa mengisolasi diri setelah terkena deteksi musim pandemi di tahun 2019. Gejala pasti tiap orang yakni mengalami demam, batuk, dan sesak nafas. Orang yang sangat didiagnosa akut berat mengalami gagal ginjal bisa orang tersebut bisa meninggal dunia.

Adakalanya setiap orang lebih mudah tertular wabah pandemi dilihat dari sisi daya tahan tubuh/ imun manusia, dan orang tersebut sudah memiliki penyakit-penyakit yang sudah melekat pada dirinya kayak penyakit asma, lemah jantung maupun penyakit- penyakit lainnya. Penyakit- penyakit inilah sebagai langkah awal tentang awal wabah pandemi menjalar keseluruh tubuh ditularkan dengan percikan batuk, adapun obat wabah pandemi belum jelas apa nama kesembuhannya. 
Maka hal yang bisa dilakukan sekarang adalah menekan laju penyebaran COVID 19 dengan langkah-langkah sebagai berikut:

- Sering-sering membiasakan keseharian cuci sabun dengan waktu 20 detik, apabila tidak bisa maka dapat menggunakan hand sanitizer atau juga bisa menggunakan alkohol $60 \%$.

- Jika keluar rumah selalu menggunakan masker, baik itu masker untuk medis ataupun hanya masker kain.

- Melakukan sosial distancing minimal dengan cara 1 meter, dan jauhi keramaian.

- Jika tidak ada alasan yang darurat maka di rumah saja itu lebih baik.

- Tidak disarankan jika menyentuh mata, hidung, dan mulut apabila tangan-tangan lagi kotor.

Dampak psikologi yang muncul di masyarakat akibat dari

COVID 19 menjadikan hidup masyarakat menjadi tertekan karena faktor-faktor berikut:

- Resiko terinfeksi dan mengifeksi orang lain, apabila belum $100 \%$ diketahui.

- Gejala umum manusia ditandai demam adalah penyakit COVID 19.

- Pengasuhan anak-anak karena sekolah ditutup atau sedang diliburkan adanya wabah pandemi tanpa memperhatikan protokol kesehatan yang tepat.

4. Manusia mengalami penurunan kesehatan fisik pada orang berusia lanjut dan penyandang disabilitas saat sudah dikarantina dan tidak adanya dukungan-dukungan lain agar segera sembuh (https://en.wikipedia.org/wiki/Impact_of_the_201920, 24 Mei 2020 ).

\section{Penyebaran COVID 19 di Indonesia serta Kebijakan Pemerintah Mengenai Pendidikan di Indonesia}

Penyebaran COVID 19 yang semakin meluas di berbagai daerah di dunia, tepat 7 Januari 2020 mengidentifikasi wabah pneumonia di negara Cina tidak diketahui etiologinya dari jenis wabah pandemi alias wabah corona virus (novel corona virus, 2019). Indikator kasus-kasus manusia yang bisa terinfeksi wabah pandemi diawali wilayah wuhan negara cina menuju negara tetangga bahkan 
sampai indonesia. Untuk itulah negara Indonesia harus tetap semangat melawan wabah pandemi.

Lonjakan kasus COVID 19 semakin hari semakin menjadi, akibatnya banyak sektor yang terkena dampaknya. Bukan hanya berdampak pada dunia ekonomi, melainkan dirasakan pula pada dunia pendidikan. 10 negara memiliki penutupan sekolah yang teralokasisasi, UNESCO memperkirakan 473.933 .356 pelajar berpotensi beresiko (pendidikan pra sekolah dasar hingga menengah atas) dan 77.938.904 pelajar berpotensi beresiko dalam pendidikan tinggi. Virus tersebut juga dengan cepat menyebar diseluruh daerah di Indonesia, bahkan sampai kepada daerah-daerah yang bias dikatakan daerah pelosok. Diketahui saat ini per 11 Mei 2020 jumlah korban yang diidentifikasi terjangkit virus ini bertambah 233 orang, sehingga total korban menjadi 14.265 orang. Kemudian pasien yang dinyatakan sembuh menjadi 183 orang jumlahnya, total keseluruhan 2.881 orang teridentifikasi penyakit.

\section{Dampak COVID 19 Pada Proses Belajar di Sekolah}

Gangguan wabah Covid-19 saat ini menjalar ke seluruh negara termasuk Indonesia tercinta, tentu hal ini menjadi tolak ukur dari pemerintah dalam mengelola kebijakan di sekolah-sekolah. Dimana sekolah adalah lahan pertemuan manusia dengan lainnya dengan anggapan lokasi perjumpaan dalam idealisme transformasi berbagai pengetahuan dan ladang peningkatan sektor ekonomi. Sekolah bisa mengoptimalkan daya sosial dan sadar akan interaksi sosial antar guru dengan para siswa. Media termudah jalinan sosial dijalankan atas berbagai kegiatan di lingkungan sekolah.

Dunia pendidikan Indonesia sedang mengalami kecerobohan yang sangat berarti dilihat bahwasannya pemerintah sangat terpukul dengan banyaknya manusia Indonesia yang tertular wabah pandemi ini, untuk itulah new normal adalah cara pemerintah menghentikan penularan antar manusi dengan manusia lainnya. Kebijakan selanjutnya tiap sekolah harus menyediakan tempat cuci tangan minimal 2 tempat yang khusus dipasang pada lingkungan sekolah. Tidak terkecuali selalu memakai masker, dan hidup sehat tanpa waswas serta sadar hakikat penyakit wabah. 
Kegiatan pengajaran di lingkungan sekolah sudah tak asing lagi via virtual atau sekarang mudah dikenal via daring. Pemanfaatan teknolologi internet sudah ditemukan banyak masalah, sehingga sangat menghambat efektivitas kegiatan pengajaran yakni:

\section{Keterbatasan Teknologi Informasi yang mumpuni}

Para pendidik ataua guru sangat bingung tentang cara menjalankan teknologi kekinian apalagi para guru senior (guru yang dilahirkan sebelum tahun 1970-an). Keterkaitan pemakaian media teknologi antara guru dan siswa sangat berarti dalam terjalinnya connecting sistem pengajaran via daring. Kebijakan pemerintah tentu dinantidinanti oleh berbagai lini sekolah yang nota bene masih belum meratanya teknologi modern.

\section{Sarana dan Prasarana sekolah yang masih mengenaskan}

Masih saja berkutik dalam kemajuan teknologi modern yang ditandai masih ditemukan para guru diangka kemiskinan dan kurangnya perhatian kesejahteraan identitas sosial, dan nilai ekonomo para siswa yang berada digaris kemiskinan serta ekonomi yang mancet dialami seluruh wilayah negara Indonesia. Inilah tonggak kejelasan pengukur keberhasilan nilai para siswa setelah wabah pandemi menjalar di lingkungan sekolah mereka.

\section{Akses Internet yang terbatas}

Lagi dikejutkan sistem jaringan internet yang kurang merata terkhusus wilayah terpencil, sehingga jaringan internet sangat terganggu dan tidak lancar. Apalagi lembaga pendidikan yang susah signal dan luas wilayah jarang dilewati oleh kendaran berakibat kurangnya perhatian baik pemerintah setempat dan pemerintah pusat.

\section{Tidak ada Anggaran biaya}

Juga yang menggangu pembelajaran interaksi antar guru dan siswa via daring, biasanya beli biaya internet tetap berasal dari uang pribadi. Ada anjuran pada tiap sekolah akan sistem pembelajaran via daring kucuran dana buat kuota internet belum juga diberikan kepada tiap sekolah. Hal ganjal inilah yang membuat gaduh segala lini terutarama orang tua yang mengidamankan para siswa bisa pintar dengan materi matapelajaran, untuk inilah kerjasama diantara 
sekolah, guru dan siswa sangat mewujudkan pembelajaran via daring tanpa merugikan salah satu pihak.

\section{Dampak pada Lulusan Sekolah}

Banyak gejala yang ditemukan di lapangan pekerjaan indikasi gaduh tentang daya kerja atau tampungan akan butuhnya aplikasi keilmuan baik para lulusan perkuliahan maupun lulusan sekolah (Rusman, 2013: 23). Dampak nyata inilah yang sangat menekan dalam pikiran para lulusan perkuliahan maupun lulusan sekolah yakni tergancal susahnya mengais rezeki apalagi banyak PHK dimanamana akibat wabah pandemi Covid-19. Mendapatkan kerja susah apalagi mau kerja sesuai gaji yang diharapkan, untuk itulah mental para lulusan harus diasah baik orang tua maupun mahasiswa / siswa wajib mengerti dan memahami resika lini lapangan yang harus dihadapi (Robert E Slavin, 2009: 22). Persaingan karier inilah terbaca jelas kebingungan para lulusan apalagi segala tempat kerja dihubungkan tanpa ada pengalaman maka para lulusan dinomor urutkan kesekian kalinya (Sugihardjanto, dkk. 2003: 34).

\section{Dampak terhadap Siswa}

Adanya wabah pandemi Covid-19 yang sedang melanda bumi pertiwi (Indonesia) hal ihwal yang sangat mengesankan ialah kebijakan pemerintah belum berpihak kepada siswa, dikarenakan banyak siswa di negeri Indonesia berat dalam segi ekonomi mau beli beras dan sembako saja susah apalagi mengikuti pembelajaran internet dengan memiliki handphone, laptop ataupun komputer yang harus diada-adakan dalam waktu dekat. Kejadian yang berbeda lagi adalah masa pandemi guru dan siswa harus terbiasa jaga jarak dan membiasakan cuci tangan dengan harapan tidak tertular wabah pandemi ini. Situasi pembelajaran yang sedikit berbeda dulu pembelajarn dilaksanakan dilingkungan sekolah kini harus via virtual (pembelajaran online).

Dampak yang dialami siswa, jika keseringan libur lama-lama menyebabkan anak jadi terbayang-bayang bagusnya kegiatan transfer keilmuan di lingkungan sekolah yangmana sebelum wabah pandemi terjadi pada seluruh negara kegiatan bermain, bercanda dan saling sapa secara langsung, siswa tidak bisa lagi akrab tanpa jarak memisahkan. Hal seperti inilah yang diinginkan para siswa tetapi 
kondisi wabah tidak memungkinkan (Sumiati dan Asra, 2009: 46). Tiap warga sekolah (para guru dan siswa) harus memperhatikan aturan protokol kesehatan diawali sering cuci tangan, pakai masker dan jaga jarak dimana saja. Dampak negatif yang akan dialami siswa memiliki anti sosial jika telah bergabung atau berjumpa dengan siswa lain, teman, guru maupun orang lain disebabkan anak-anak harus selalu berada dilingkungan rumah dan wabah pandemi yang belum juga usai atau selesai. Kejadian wabah ini mengajak siswa agar terbiasa akrab dengan dunia teknologi, berakibat siswa siaga dimana saja dan siap belajar adaptasi sistem jarak jauh menggunakan teknologi modern.

Hal ihwal yang mengharuskan pihak sekolah agara alat teknologi dipersiapkan dan sistem pembelajaran dimulai bimbingan kepada stakeholders (orang tua). Inilah capaian yang digadangdigadang oleh stakeholders (orang tua) agar dana keuangan keluarga tercukupi tidak terfokus buat kebutuhan kuota internet. Pembelajaran di rumah sangat menganggu anak usia umur 1 sampai 3 tahun yang harus selalu didampingi saat proses virtual dilaksanakan karena anak tersebut belum bisa mengoperasikan pembelajaran online. Dengan demikian orang tua sangat berarti demi keberhasilan pembelajaran agar anak paham dan anak dapat mengelola materi pembelajaran.

\section{Dampak terhadap orang tua}

Orang tua dalam kehidupan sehari-hari harus dapat mencukupkan segala apa yang diindahkan oleh segenap penghuni dalam rumah, pembelajaran virtual ini juga anak atau siswa harus bisa membeli kuota internet agar bisa lancar dalam mengikuti pembelajaran virtual dalam seminggu. Jadi, beban kebutuhan orang tua bertambah dan harus ada walau jauh harapan apalagi ekonomi dunia sedang lemah atau pengeluaran tiap keluarga makin banyak dan tidak bisa dijanjikan sampai kapan akan berakhir. Kendala yang berarti orang tua memiliki anak usia dini harus bimbing dari segala arah yakni mengendalikan handphone, nunggu acara pembelajaran virtual selesai tiap hari dan materi yang harus dikerjakan. Untuk 
itulah situasi akademik saat wabah pandemi masih merajalela ini sangat menyiksa orang tua dari sisi kebutuhan makan maupun jumlah kuota internet. Penghasilan masa wabah pandemi jumlah gaji berkurang apalagi ada pembelajaran virtual orang tua harus sibuk update pembelajaran virtual dan menyelesaikan tugas dari para guru.

Aktivitas masa wabah pandemi ini orang tua harus menguasai pembelajaran virtual dan bisa otodidak dalam menyelesaikan tugas sekolah yang diberikan kepada para siswa. Akibat pembelajaran virtual bisa saja orang tua mau menerima keadaan atau ditemukan para orang tua marah kepada guru. untuk itulah sikap saling mengingatkan dan kekompakan antara guru dengan para orang tua bisa dinamis sehingga pembelajaran virtual lancar dan materi bisa dikuasai sehingga mewujudkan para siswa pintar. Kendala inilah yang harus dilalui oleh para guru terlebih banyak proses atau materi yang wajib dikuasai sebelum melakukan kegiatan pembelajaran virtual.

\section{Dampak Terhadap Guru}

Sekolah sebagai komunitas dalam memberikan keilmuan baik guru, para siswa maupun orang tua harus sigap tentang kejelasan pengadaan fasilitas penunjang pengadaan pembelajaran virtual. Fasilitas dari pihak sekolah ini sangat penting dominan dalam kebermaknaan proses belajar mengajar. Bagi guru yang belum akrab dan sudah usia senja perlu perhatian serius dan bimbingan teknis dalam pengoperasian teknologi sehingga para guru yang usia tua tidak lagi bingung tentang kendali pembelajaran virtual. Apalagi tugas negara dalam mengapresiasi pengetahuan yang layak kepada para siswa dalam mencerdaskan generasi bangsa sangat ditungguditunggu oleh para guru maupun bantuan kuota bagi orang tua. Jika sekolah mampu membeli laptop, computer ataupun hand phone terbaru sangat dominan menghasilkan sistem pembelajaran modern dan para siswa senang karena bisa memahami tematik-tematik pelajaran. 


\section{Simpulan}

Adanya virus wabah ini sangat dirasakan baik guru, para siswa maupun orang tua, sehingga ketergantungan saling memahami dan menyukseskan pembelajaran merupakan acuan pasti yang harus dilaksanakan. Tiap orang harus menjalani new normal dan terbiasa melaksanakan protokol kesehatan sesuai anjuran pemerintah setempat sehingga seluruh manusia sehat dan bisa melaksanakan tugas kesehariannya. Jadi, pemanfaatan handsitier dan cuci tangan harus sebagai awal kegiatan bagi tiap orang, apalagi wabah pandemi ini tidak bisa dijadwalkan kapan selesainya. Kesinambungan kesadaran dan perilaku sehat adalah acuan keuntungan baik diri sendiri, keluarga maupun bisa bergaul bebas seperti tahun-tahun sebelumnya (tanpa wabah pandemi). 


\section{DAFTAR PUSTAKA}

Anas, Muhammad. 2014. Mengenal Metodologi Pembelajaran. Pasuruan: Pustaka Hulwa.

Arifin, Zainal. 2013. Evaluasi Pembelajaran. Bandung: Remaja Rosdakarya.

Arikunto, Suharsimi. 2010. Prosedur Penelitian Suatu Pendekatan Praktik. Jakarta: Bumi Aksara.

Arikunto, Suharsimi. 2013. Dasar-dasar Evaluasi Pendidikan. Jakarta: Bumi Aksara.

Dalyono, Muhammad. 2010. Psikologi Pendidikan. Jakarta: Rineka Cipta.

Desmita. 2014. Psikologi Perkembangan Peserta Didik. Bandung: Remaja Rosdakarya.

Hamdayama, Jumanta. 2014. Model dan Metode Pembelajaran Kreatif dan Berkarakter. Bogor: Ghalia Indonesia.

Huda, Miftahul. 2014. Model-model Pengajaran dan Pembelajaran: Isu-isu Metodis dan Paradigmatis. Yogyakarta: Pustaka Pelajar.

Rusman. 2013. Model-model Pembelajaran Mengembangkan Profesionalisme Guru. Jakarta: Rajawali Pers.

Slavin, Robert E. 2009. Psikologi Pendidikan Teori dan Praktik. Jakarta: Indeks.

Sugihardjanto, dkk. 2003. Globalisasi Perspektif Sosialis. Jakarta: CBooks.

Sumiati dan Asra. 2009. Metode Pembelajaran. Bandung: Wacana Prima. 
https://id.wikipedia.org/wiki/Penyakit_koronavirus_2019

https://en.wikipedia.org/wiki/Impact_of_the_201920_coronavirus_pa ndemic_on_education

Taufik, A. (2019). Pengembangan Kurikulum Pendidikan Islam. ElGhiroh, 17 (02), 81-102.

Taufik, A. (2020). Dakwah Islamiyah Melalui Media Bahasa Arab. khabar, 2 (1), 33-41. 